\title{
Universiteit
}

Leiden

The Netherlands

\section{At home on the margins: care giving and the 'un-homely' among Casablanca's working poor \\ Strava, C.}

\section{Citation}

Strava, C. (2017). At home on the margins: care giving and the 'un-homely' among Casablanca's working poor. City \& Society, 29(2), 329-348.

doi:10.1111/ciso.12129

Version:

Publisher's Version

License:

Licensed under Article 25fa Copyright Act/Law (Amendment Taverne)

Downloaded from: $\quad$ https://hdl.handle.net/1887/3202265

Note: To cite this publication please use the final published version (if applicable). 


\section{At Home on the Margins: Care Giving and the 'Un-homely' among Casablanca's Working Poor}

\section{Abstract}

In this article I examine some of the ways in which giving and receiving care on the margins of Casablanca become ambivalently constituted acts inscribed in a context of historical trauma and growing economic insecurity. Within this context I explore the usefulness of "un-homely" as a conceptual tool for discussing forms of domestic care on the margins of a growing urban center. Drawing on fieldwork material gathered during 2013-20I4 in a marginalized and criminalized neighborhood in Casablanca, I use an ethno-historical approach to unpack the production of marginalization and poverty, and explore which forms of care are available to urban lower class women in particular. With the help of my closest interlocutor, Amina, I offer a discussion on the labor of caring, for oneself and of others, as well as the particular affect associated with this labor. I suggest that such skilled routines of caregiving do not only function as a coping mechanism for women in precarious situations, but they reproduce affects of unhomeliness as much as they contain them. I argue that it is this ambivalent weaving, between containment and acceptance, that ultimately serves to help make precarious homes and uncertain futures livable. [margins, un-homely, care giving, routines]

\section{Introduction}

$\bigcirc$ ne day in February 2013, towards the beginning of my fieldwork in Casablanca, ${ }^{\mathrm{I}}$ Amina ${ }^{2}$ invited me to have lunch at her house. Heading off one of the main streets of her neighborhood, we walked into a narrow pedestrian alley and passed through the arched gates of a workers' estate built in the r940s by colonial industrialists. Stepping out through another arched gate we arrived at Amina's derb, or quarter. The houses there were more densely built, taller and closer together. The floors looked precariously stacked on top of each other, their façade details resembling slices of a layer cake gone askew. Amina's small alleyway was littered with food wrappers and organic waste, trash gathering in clumps around the mouths of sewer openings. Children ran up and down in games of catch, oblivious to the large dead rat in the middle of the street.

Amina's house was identical to the ones lining the street on both sides. The entrance door was ajar and I could see a tiled, dark and narrow staircase ascending to the upper floors. Amina lived on the ground floor, her door a few paces behind the main entrance to the building. Stepping inside we were greeted by darkness until she turned on a naked bulb hanging from the high ceiling. With the exception of an air vent above 


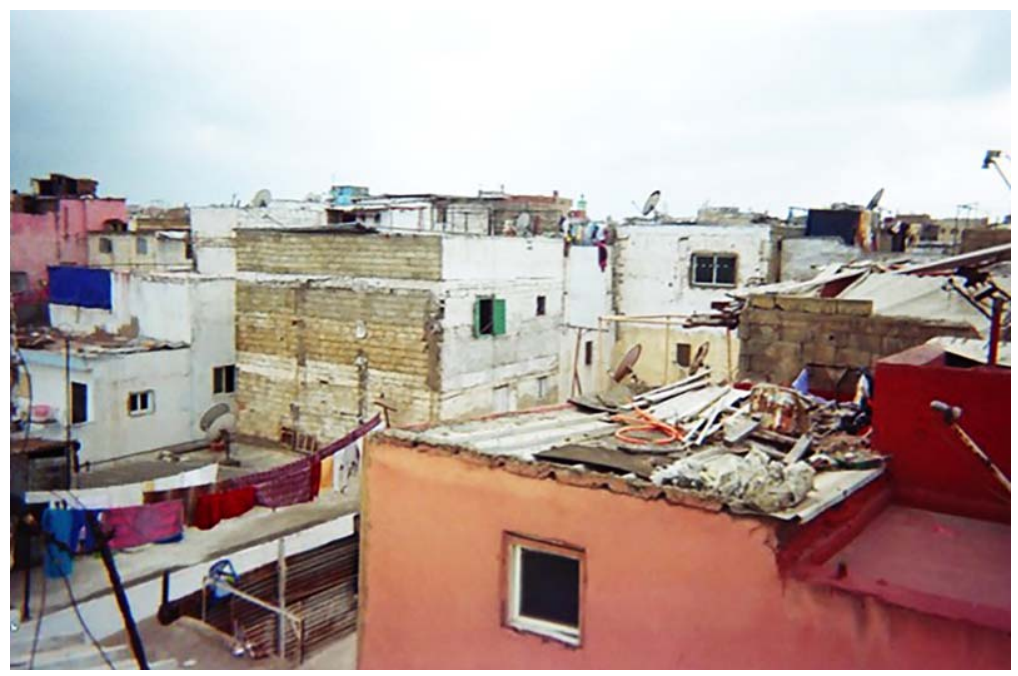

Figure I. Amina's derb. Picture taken by Reda, one of my research collaborators, 20I4. [This figure appears in color in the online issue.]

the entrance door, there were no windows, since this part of the building had initially been an open patio that was now closed-in in order to build further floors. Originally built as part of a French colonial project for 'acclimating Moroccans' to urban life and providing them with 'healthy' dwellings (Rabinow i989), Amina's ground floor dwelling had become the opposite of aerated and sunny.

Amina lived there with her sister whose chronic illness made her completely dependent on Amina. I was invited to sit down in the small salon as Amina began to prepare lunch. The forty-eight square meters that made up the home were divided disproportionately between the kitchen, the foyer and two small rooms. The foyer took up the most space in the center of the house, while all the other rooms lined its sides and opened onto it. A minuscule washroom had been squeezed under the staircase that led to the upper floor apartments. Separated from the foyer by a wooden door on a latch, the limited space served as both squat toilet and shower room. Amina embarrassedly asked me to ignore the smell that came from its direction, saying plumbing was as old as the quarter and in need of fixing. To the other side of the entrance door the kitchen was not much larger than the washroom, its space easily filled by one person alone.

The salon was long and narrow, connected to the foyer by an opening framed by a gauzy silver and white curtain. Lining each wall were low, rectangular cushions covered in a velvety, floral-patterned fabric whose silvery details matched the curtain. This was the only room in the house that was carpeted, so I slipped my shoes off before stepping in and taking a seat. The TV had been mounted on a high wooden shelf nailed into one corner, which freed up the space, but also mirrored the ubiquitous display of TVs in local cafés. Bringing out a bag full of the medication that she usually took with her lunch, Amina told me she also suffered from an autoimmune disease, whose onset she traced back to her mother's death from cancer a few years ago. Her father's death, also from 
cancer, took place some years before the loss of her mother. Although unsure about the details of her parents' illnesses, Amina vaguely suspected a link to their jobs in the nearby sardine-packing factory.

Amina was in her early thirties at the time of my fieldwork in 201320I4, having grown up and lived her entire life in the Hay Mohammadi neighborhood, infamous for the underground detention center that operated there at the height of Morocco's 'Years of Lead', a period known for human rights abuses of the former King Hassan II. Amina's parents had migrated to the city from Morocco's rural areas during the I970s. Amina never met her rural kin, and neither of her parents took her on visits to the bled, their home village, while they were alive. In fact, Amina claimed that until she was eighteen years old she had never left the neighborhood. The loss of both her parents both opened and shrunk Amina's world. An older sister had travelled abroad and kept only minimal contact with Amina, who had been left to care for her disabled younger sister.

Unlike the inhabitants of an adjacent quarter who suffered from illnesses directly related to the sugar refinery that coated their lives in a thin layer of sweet, asthma inducing dust, Amina's ill health was more tenuously linked to the degradation of her area. Asking her to tell me how she liked living there, her answer was that she did not. "It is a bad (khayb) and dangerous area, poor, ugly (mazwinch) and dirty; but we make do," she concluded in French (Mais, on fait avec).

In this article, I want to ask what it means to live and to care-for oneself and for others-in a place of 'making do'. I focus in on Amina's story as an example of navigating the ambivalent complexities of living amongst ruination. Tracing her daily habits of care for herself, her sister and her home, I draw on Freud's notion of the 'un-homely' to describe the ways in which Amina and her neighbors have come to live with the specter of displacement, degradation and uncertainty that has entered into their homes. Several theorists, including Yael Navaro-Yashin, Veena Das, and Clara Han have taken up the notion of the 'un-homely' to complicate our notions of domesticity. Navaro-Yashin speaks of the un-homely as a constant affect, which homemakers continually strive to pacify and subdue, to regain a sense of the peaceful home (2012). Das $(2007,2008)$ and Han (2012), in contrast, talk about the ways in which the marginal learn to 'make do' with degradation and uncertainty, and describe forms of caring that are less about re-asserting control and more about accepting, doing the best one can, and waiting for new possibilities to emerge. Here I want to extend these proposals by arguing that in places like Hay Mohammadi, where Amina lives, people do not simply 'make do' with un-homeliness, but walk a fine line, sometimes seeking to contain it, and sometimes embracing it as a part of their sense of home. As such, their routines of daily care do as much to reproduce affects of un-homeliness as they do to contain them. And it is this ambivalent weaving, between containment and acceptance, that I want to argue ultimately serves to help make precarious homes and uncertain futures livable.

I begin with some brief historical background on the social, political and economic processes that led to the construction of Hay Mohammadi in places like Hay

Mohammadi

where Amina

lives, people do

not simply 'make

do' with

unhomeliness 
as a socially and geographically marginal space. I continue with a biographical approach that explores how a sense of un-homeliness is produced or comes into being for women in precarious situations living on the margins of Casablanca. The next three sections explore the different mechanisms and forms of routinized care applied to both bodies and domestic spaces. Moving from a consideration of how gendered skills are tactically employed to secure care for oneself and others to the laborious acts applied to bodies and homes, I discuss how such acts work to both keep un-homeliness in check and to incorporate it into everyday life.

\section{Locating Casablanca's margins}

$\mid$ ay Mohammadi was built on the gaping holes of a stone quarry, from where it borrowed its initial name, Carrière Centrale (or Karyane Centra $^{3}$ as the locals still referred to it), and quickly became a symbol of fast paced industrialization and urbanization during Morocco's colonial era. ${ }^{4}$

By the I950s Casablanca's bidonvilles were becoming a growing issue for the French administration. ${ }^{5}$ Morocco's urban population had increased by 232 percent from I930 to I946, while the colonial housing policies vis-à-vis Moroccans remained unchanged from the pre-war era (Écochard I955a: 38). In Casablanca, the growing numbers of rural migrants were expected to live either in the increasingly overcrowded old medina or to rely on the insufficient housing provided by their industrialist employers. ${ }^{6}$ Confronted with these conditions Michel Écochard, the head of the Service de l'Urbanisme (Urban Planning Service) between I947 and I953, began to devise a plan for providing Moroccans with affordable housing. Until that point the strategies used by the Service to deal with an increasing amount of informal housing oscillated between re-ordering the shanties and providing temporary re-housing in the form of wooden shacks (Écochard I 955, 47). During his brief tenure Écochard experimented with the creation of new housing estates based on a standard eight-by-eight-meter grid (Cohen and Eleb 2002, 319). ${ }^{7}$ Amina's quarter and the great majority of Hay Mohammadi evolved from this Cartesian organization of space that was meant to reign in the Karyane and promote a triumphant modernity (Mitchel 2002, Avermaete 2005). The grid promised a rational solution that would provide workers with housing that fostered order, hygiene and productivity.

As the materialization of this social utopia was underway, Karyane Centra was at the forefront of violent clashes between the French and local labor unions, which eventually culminated in the proclamation of Independence in 1956. With the return of the exiled King Mohammad $\mathrm{V}$ the neighborhood changed its name to honor the monarch and inaugurate a new era. Meanwhile, the squat patio homes of the eight-by-eight grid began to expand vertically, adding new floors as families grew, and each decade saw a new attempt at reigning in the Karyane or trying to dismantle it. 
Starting with the late 1960s, due to a toxic blend of political and economic circumstances the neighborhood entered a phase of increased degradation and impoverishment. Beginning with the 1965 student uprising ${ }^{8}$ and culminating with the 198 I 'bread riots', ${ }^{9}$ Casablanca and Hay Mohammadi in particular became the scene of grave human rights abuses and state violence. The same spirit that had brought the labor unions of Hay Mohammadi to the forefront of the anti-colonial struggle was unwelcome to the successor of the reinstated monarch. Hassan II took the throne in I96r and ushered in a period of unprecedented brutality against all forms of dissent. Union and student activists alike were forcefully disappeared and sent to secret prisons where they were tortured for years. Amina's quarter came to house one of the most infamous detention centers in the country, where hundreds of activists were held and tortured underground for years while their jailers lived in a modernist tower block above ground (El Bouih 2008; Slyomovics 20 2 2; Taki 20I5).

The oppressive silence surrounding these and other traumatic events was finally broken when in 2004 the Moroccan Equity and Reconciliation Commission (ERC) was created by current King Mohammed VI. The only truth and reconciliation commission in the Arab World to date, the ERC's main mandate was to investigate the forced disappearances and arbitrary arrests that took place between I965 and 1999. In its report released to the public in 2006 , besides acknowledging individual victims, the Commission established the existence of a number of "wounded territories" (territoires touchés) in recognition of the community dimension of human rights violations.

In an interview I recorded in March 2013, Fatna El Bouih, a wellknown former detainee, argued that the state tried to crush the communal spirit of Hay Mohammadi.

Judges [who] grew up in the karyane (shanties), boxing champions, the TAS football team, journalists, activists [...]. They did not like this spirit of these people rising up and criticizing the power. Crushing bodies was not enough. They instituted hissar (siege), you understand? It was like they created an embargo on the area, marginalized it to punish the people.

Several urban planners I interviewed also acknowledged that the neighborhood had been targeted with a combination of Haussmanian planning measures known today as the 'Emergency urbanism' era, and the slow starving of resources that led to its effective ghettoization during the 1980 (Rachik 2002). Wide roads were built as quick access corridors that were later used by army tanks to quell protests during the 198I riots (Ossman I 994). Si Mohammad, another prominent neighborhood figure and a journalist during the I96os, told me that when administrative redistricting in 1991 fragmented the neighborhood into new sectors some inhabitants interpreted it as further proof of the state trying to break up the community. By designating Hay Mohammadi as a "wounded territory" the commission cemented the already strong link identifying the 
material space of the neighborhood with a social geography of state violence, controlled poverty and trauma. Indeed, many of my collaborators in Hay Mohammadi conceptualized the scarcity and struggle of the present as the enduring effects of past state violence and neglect.

While material reparations are still underway a number of cultural projects have been encouraged and funded by the ERC. One such project carried out by a small group of local NGOs was meant to produce a collection of oral histories accompanied by a commemorative map, designating forty sites in the neighborhood as lieux de memoire (cf. Nora 1989). As a recent university graduate looking for temporary work, Amina was recruited as an interviewer for the project back in 20II. For her this was the first time she learned of the violence that had taken place only paces away from her home. She now suspected that the underground prison stretched all the way to her house, although none of the inhabitants knew for sure since they have not been allowed to visit the now closed detention center. "Who knows? There might be cells leading right under our floors", Amina said with concern as we were sitting down in her salon for lunch. Since its closing in 1997 there has been talk of turning the detention center into a museum but in the meantime it serves as a branch of the local administration.

However, in spite of the many indignities suffered by the neighborhood, the buildings and the community continue to endure, not without a certain sense of pride. Having to live not only with a history of state violence but within the physical space that bears the marks of that trauma, the inhabitants of these marginalized spaces have become adept at what Das has described as the "folding" of trauma into the "ordinary" fabric of everyday life $(2007,7)$. Amina's case speaks to how the increasing precarious nature of life on the urban margins compels people to elaborate, as well as accept, new forms of care, both individually and as a community. Very often these are not exceptional, but mundane acts, invested with the ambivalence that weds together a sense of temporary well-being with the constant threat of insecurity.

\section{The 'un-homely' margins}

Over the course of my fieldwork I became very close to Amina, staying overnight at her invitation, visiting often, celebrating religious feasts together, and occasionally going on outings in the city. I want to focus in on Amina's story to unpack how the 'wounds' and insecurities of Hay Mohammadi are folded into everyday life (Das 2007, 2008). It is only by looking closely at Amina's life that this becomes apparent, as these ruptures of everyday life may make themselves known pervasively, but often only by surfacing in small and mundane details. As such I follow other ethnographers in taking a biographical approach that allows me to zoom in on such details (cf. Crapanzano I980; Kleinman 2007; Biehl 2013). Indeed, if I am suggesting that historical wounds and present insecurities color most lives in Hay Mohammadi, then this is nonetheless a process that is likely to occur in different ways and to different extents from person to person. 
To begin, I want to look at how such wounds and insecurities became manifest for Amina, in everyday life. A significant dimension of the insecurity Amina felt revolved around her status as a single carer and provider for her sister and herself. It became clear to me over time that while her family situation was uncommon, it was not all that dissimilar from other residents I met through fieldwork, a majority of whom had lost kin to chronic illness or work accidents. What was less common was the fact that as a young unmarried woman, Amina and her sister lived without an older female or male guardian. Although it was not unusual at the time of my fieldwork for young women from wealthy families to live independently in a city like Casablanca, women in lower class positions were less likely to live completely outside the care and control of older kin.

Right after my mother died, some relatives said I should go live with my aunt. But I did not want to; [...] I didn't want to bother them. My cousin then told me, 'You can live on your own. You are old enough and responsible, you can take care of yourself, right?' And I think this is the best thing for me. I don't have to answer to anyone like this.

Of course, this was not entirely true, as Amina did not only have to care for herself, but also for her sister, and often talked about the pressure of living under the perceived daily surveillance of her neighbors. Living on her own also meant that when her landlord tried to increase her rent after the death of her mother, Amina had very little direct family support to fight the decision.

I was very young, twenty years old. I had to fight hard to convince the mul dar (owner of the house) not to do it. I went to the medina where he lives in a big house, and pleaded with him. I brought alweraq (the documents) my mother left me. [...] I went to the muqata'a (public notary) and got my documents legalized. It was a lot of work but in the end, I succeeded.

Despite the challenges she encountered when she found herself alone, Amina told me this story not without a sense of pride and empowerment that she clearly derived from her victory over the landlord. Amina associated the ability to deal with such contingencies and the effects they had on herself with ideas and perceptions of her own physical and mental well-being. While clearly proud of the way she had handled the situation with her landlord, Amina insisted that the sense of material insecurity that her housing situation created took a toll on her health. Moreover, Amina often spoke of the psychological and social burden of living under the perceived surveillance of her community and close neighbors. On many occasions when she asked me to join her on errands or for a rare leisure visit into downtown Casablanca, Amina would guide me along a carefully chosen succession of streets, arguing that her neighbors need not know her every coming and going. On these same occasions Amina tried to explain to me the difficulties of attempting to bring her sister along and thus why she would have to remain home alone. It 
pained Amina that the home did not even have a window where her sister could look out from in the absence of the possibility of going out. Thus, the sense of unrelenting surveillance, the complicated responsibility to care for her sister, and her own chronic illness were intimately, but also ambiguously linked in Amina's mind to her place of dwelling.

As her childhood home, the house remained a meaningful place for Amina, invested with happy memories of past times. But homes are not constant felicitous places, and the work of feminist scholarship has contributed greatly to rethinking previous work on domesticity (cf. Bachelard I994[1964]; Massey I994; Blunt and Dowling 2006; Hollows 2008). As Amina traced the onset of her illness to the death of her mother, the house and her body became linked by the experience of trauma and loss. A recurring anecdote Amina was fond of telling revealed the way in which the corporeal senses became linked to this experience of home undergoing a profound transformation: "When my mother was in the hospital before she died, my cousin came to cook for us, and she prepared a tagine (stew), but put bay leaves in it. We hated it! My mother never cooked with bay leaves. To this day I can't eat them." The bitter taste of bay leaf connected Amina to the loss of her mother's care and home-cooked meals. This loss seemed to amplify those material elements of the home whose lack of warmth and familiar pleasure had maybe been ignored until that point. Throughout our conversations Amina repeatedly mentioned how after the death of her mother the home no longer felt welcoming.

While Amina cherished her dwelling as a place where textures were familiar and whose organization and display she often creatively engaged with, this home was also the decaying, "khayb" (bad) architecture that housed her sister who waited everyday day for Amina's return from work. Adding to this was a growing communal awareness of the history of state violence that had left its marks on Amina's quarter, most notably in the continued presence of the underground detention center. Nevertheless, there were times when Amina preferred to spend the weekend inside her home, and I often failed to coax her to join me for a sunny walk outside, as she argued that she would much rather enjoy the coziness of her home, stressing that this made her feel hanya (relaxed, at ease). As I poured over my fieldnotes and attempted to understand the ambivalent feelings of uneasy well-being Amina expressed about her domestic situation, I began to consider how the concept of "un-homeliness" might help to unpack this paradox. Here I would like to turn to Freud's elaboration of the "un-canny" (I9I9) as an entry-point into exploring how 'ordinary' forms of trauma and loss become woven into processes of caregiving and homemaking.

Starting from an earlier analysis provided by Ernst Jentsch (I906), and based on literary as well as psychoanalytical case material, Freud proposes to explore the nature of what he calls the unheimlich as a psychic state that may give rise to feelings of fear, dread or eeriness. Although uncanny seems to be the preferred English term, Freud also noted that a closer etymological translation would be "un-homely" ( I9 I9, I24). In his 
analysis, Freud argued that the uncanny was not merely that which was unfamiliar, but also something that had once belonged to the familiar and protected space of the home, but which had become alienating and frightful. As Navaro-Yashin (2012, I 82) observed in her study of domestic appropriations in contested Northern Cyprus, the 'un-homely' can therefore serve as a powerful analytical category for exploring the ambivalent affect evoked by particular dwelling contexts charged with a history of state violence and personal trauma.

Building on Freud, Homi Bhabha (I994) argues that the un-homely is a paradigmatic post-colonial experience. According to his reading, the un-homely has a definitive spatio-temporal dimension present in the historical moment marked by the intrusion of the world into the home, and the inversion of the physical space of the home from a reassuringly intimate place of shelter and rest into a realm that is marked by contingency and displacement. Anthony Vidler ( I992) further emphasizes this spatial dimension by going back to the original formulation of the notion in Jentsch's work. Jentsch defined the unheimlich as a "lack of orientation" in a previously familiar situation, a sense of being invaded by something hostile and foreign in a previously comfortable setting.

For Amina, this intrusion seemed to be constituted by the emotional and financial insecurity opened up by her mother's death, coupled with the discovery of the physical spaces of historical trauma that supposedly lay beneath her feet, and the way these growing senses of dislocation reoriented her towards her neighborhood in general. As one of the densest neighborhoods in Casablanca, Hay Mohammadi continues to suffer from a chronic housing shortage and decaying public infrastructure. Insufficient waste collection services, old and faulty sewage facilities and the crumbling remains of the nearby karyane all amplified many inhabitants', including Amina's, sense of general dereliction. The loss of her mother, the compound financial, emotional and moral burdens she faced in living alone and caring for herself and her sister, and the insecurity and frustration of an unsatisfying and precarious job all heightened this ambivalent sense of insecurity within the home.

However, as Navaro-Yashin (2012) and Das (2008) both contend, beyond the direct impact and influence of historical and political forces, what if rather than being a counterpoint to a bourgeois notion of homely coziness, we acknowledged the un-homely as a central feature of domesticity? Both authors argue for those living in 'wounded' territories-former war zones, or sites of abandonment-uncanny feelings of disruption and uncertainty have become a part of domestic life and routines, and something that people have to learn to live with. And indeed, while Amina was aware of and sometimes complained about the un-homely aspects of her domestic situation, she had also managed to develop a set of practices that allowed her to keep the un-homely in check. Nevertheless, the material, moral and affective burdens and challenges placed on Amina impacted not only her ability to care for herself and her sister but also affected the way she perceived offers of help from her community. Specifically, in dealing with such daily chores and duties as caring for her
As one of the densest neighborhoods in Casablanca, Hay

Mohammadi

continues to

suffer from a

chronic housing

shortage and

decaying public

infrastructure 
disabled sister, cleaning, cooking, or simply maintaining her own emotional and psychological well-being, Amina drew on her local social networks of friends, neighbors and distant cousins.

The loss of her parents and the estrangement of her older sister meant that Amina had to develop alternative support networks. Both at work and in the neighborhood, her friendships to a large extent came to supplement traditional ties of kinship. Unlike familial relationships, she would sometimes stress, Amina felt that her friendships provided her with a more honest form of support because they were not defined by the social codes of kin reciprocity, but rather by mutual sympathy and shared life views. However, similar to what Han (2012) discusses in her ethnography of La Pincoya, Amina further distinguished between her neighbors and her friends. While she sometimes saw the former as the representatives of an oppressive surveillance culture maintained through gossip, she nevertheless benefited from what Han calls their "acts of silent kindness" (2012, 79). Several women on her street could be counted on to look after Amina's younger sister when she had to travel for work, and they would often bring Amina bowls of couscous on Fridays since they knew that it was less practical for her to prepare such a meal for only two people. They did this by insisting their actions were mere afterthoughts, which allowed them to keep up the pretense that Amina did not need their help. Accordingly, these were not acts of charity in need of reciprocation. At the same time, however, Amina sometimes refused the care extended to her as a way of asserting her own abilities and position in the community, an attitude that could be described by what Das calls the "strong ethics of endurance" (2013, 2 I 8 ).

Ultimately, Amina insisted on her self-reliance by often telling me that she was "tough" and could always "take care of herself". Her body, however, often failed her, and the chronic character of her illness made her feel helpless at times. "Look at me," she would say and point with dismay at what she lamented as a body marked by illness, the effects of stress, and medication. While Amina accepted things she perceived to be outside of her control, she compensated by developing a mastery over the material aspects of her home. As a consequence, the un-homely seemed to reside alongside her persistent work of securing a better life, forming the two faces of what Das calls domesticity: a modality of being that "combines intimacy and alienation, proximity and distance as modes of caring, loving, and grieving come into being or are brought into being" $(2008,352)$. Thus, through the bodily performance of daily routines and home-making practices, Amina worked to shore up her confidence in herself and in the future.

\section{Gendered skill}

Looking at Turkish-Cypriot homes Navaro-Yashin sees 'ruination' as seeping into people's everyday routines — in broken buildings, stolen furniture, and the felt presence of absent neighbors. Against this, she describes women's practices of homemaking as "unarticulated efforts [...] 
to overcome feelings of the uncanny, to render the uncanny less visible or less effective, to pacify its affects" (2012, I 86). In this section, then, I want to look at the ways in which Amina pushed back against unhomely affects through practices of 'skillful' homemaking. Here, the choice to approach mundane tasks through the prism of skillful practice empowered practitioners like Amina. In this section, and in the next, the role of the body and the amount of physical labor that went into this set of daily practices were not insignificant. Furthermore, I will argue that through the development of a certain degree of mastery in the execution of such daily tasks, the boundary between routine and ritual became blurred, bringing forth a new register of embodied practices. I suggest that these practices were crucial for developing forms of care meant to deal with the un-homely and alienating aspects of Amina's life in the neighborhood.

On that particular day in April when I was due to go out into town with Amina, in order to speed up our departure for downtown, I insisted that Amina let me to hang up the laundry. As she agreed, I noticed she was washing her jeans by hand in a large plastic tub placed next to the washing machine. Confused, I asked if the machine was broken. Giving me a half-embarrassed laugh she said: "No. I just prefer to wash these by hand." Without much reflection, I protested by arguing the washing machine would wash them better and faster. Offering me various reasons for her laundry washing habits, Amina concluded, almost defiantly: "I don't mind. Ana hadga! One day, when I'll get married, inchallah, I would like nothing more than to stay at home and clean all day."

Ana hadga can be roughly translated as meaning "I am resourceful," but few people stop at that when defining the term. Bringing to mind Luce Giard's “creative ingenuity” ( I998, I 59), hadga seems to encompass the myriad different abilities needed and aspired to by any good homemaker. When pushed for a precise definition, another female informant from Hay Mohammadi in her early thirties impatiently explained that hadga means simply someone who is good at everything, but foremost, a woman who is ready for marriage. Moroccan anthropologist Fadma Ait Mouss also discusses this term in her portrait of Saadia, a lower-class Casablancan housewife (20 I I). According to Ait Mouss a hadga woman is "intelligent [...] but also energetic (the opposite of a lazy woman), [...] gets up early, and is constantly doing housework" (20 I I, 5I ). As a desirable value in a good wife, hadga also seemed to inspire a wealth of Internet resources, one of which defined the hadga woman thus: "She's a hardworking, thrifty, creative, resourceful woman [...]. The triumvirate she rules by is cleanliness, thrift and nourishment." ${ }^{\circ}$ The author also mentions that a hadga woman's practices could be interpreted as unnecessarily laborious, as my own reaction shows. This was particularly visible in relation to cleaning activities. Instead of using a long-handled broom, Amina-like many other women - would stoop forward and mop the floor by working a piece of cloth called a jeffaf with her bare hands from one end of the house to the other. In order to clean the carpeted areas in 
the salon, a special small hand brush was used in a similar body pose to remove the accumulated dirt.

Despite being described as skilled resourcefulness, hadga was seldom the preferred term for qualifying work done outside the home, or for that matter, work done by a man. Amina often tried to impress upon me the aberration of men doing housework by pointing out one of her neighbors. This thin and grey-haired man frequently went around sweeping the alleyway wearing a worn-out apron with a flower pattern. Suggesting that he might suffer from mental illness, Amina told me how everyone in the neighborhood was in the habit of deriding him. Using such examples Amina discredited all my attempts to suggest that there was nothing abnormal about men doing domestic work. Through its strict association with women and the domestic realm, hadga became one of the ways in which an ideal, desirable aspect of femininity and home were produced. On many occasions I saw young girls commended for their help in the kitchen or with cleaning by an enthusiastic "tebarak Allah 'alik, nti hadga" (God bless you, you are hadga), which contributed to the re-enforcement and inculcation of this ideal.

Joanne Hollows urges us "to think about how domestic practices do not take place within a pre-given entity such as 'the family", and invites us to consider the gendering of housework as produced, performed (2008, 60 ), and, I would add, constantly re-negotiated as well as potentially deployed to accumulate particular forms of symbolic power and capital. Joan Williams has shown how working-class women might tactically deploy the image of 'family' and 'hearth' as a way of claiming a privileged position "against the injuries of class" (2000, I 57). Furthermore, as feminist scholars and anthropologists have argued elsewhere (Martens and Scott 2005), the designation of the domestic realm as women's realm should not be exclusively viewed as a form of subjugation, but might also function as a way of boundary creation through which women get a sense of empowerment and control by excluding men from that space (hooks I99I).

Here, then, I want to argue that by performing being hadga, even sometimes unnecessarily, as when she did her washing by hand, Amina was pushing back against her sense of marginality and the disruptive unhomeliness that threatened to overtake her home. At the same time, Amina's acceptance of what she saw as the gender status quo was also revealing of the manner in which she perceived her position in society, and then chose to leverage her home-making skills for the purpose of amassing a particular form of locally recognized social capital. As the 'head' of her household of two, Amina's elevation of mundane tasks to the level of prideful skill-evidenced in management of their monthly budget and her striving to provide a healthy and clean home for her ill sister-can be read as pragmatic acts of care giving. While these acts worked to keep un-homeliness in check they also served to identify Amina as a prized homemaker in her community and a potentially desirable wife.

Compared to my other female interlocutors from the neighborhood who were married and/or part of extended networks of kin, Amina was 
considerably more vulnerable in the face of contingency. She thus needed to develop alternative forms of caring for herself and her sister in the present, which were also locally recognized and valued forms of symbolic capital. Not having the benefit of a similar support networks, Amina was pragmatically inclined to become a resourceful, skilled homemaker, which would ensure her well-being both in the present as well as in the future, when a suitor would hopefully appreciate her skills and guarantee her a good marriage.

Following Navaro-Yashin, I would also argue that Mary Douglas's work on dirt echoes Freud's discussion of the un-homely. In the same way that dirt is omnipresent "matter out of place" in need of ordering, so the uncanny, or the un-homely, needs to be constantly contained and accounted for through skillful everyday routines. Hence, like NavaroYashin's Turkish-Cypriot informants, Amina too strove to demonstrate her skill not only for the purposes of performing a local form of gendered value, but as a practice of reigning in the disruptive potential and uncertainty that life in Hay Mohammadi posed. In this context, dirt and its careful management constituted a small but significant daily form of caring for the body and protecting both oneself (i.e from illness) as well as the home. This constant accounting for the uncanny, the tragic, or the negative aspects of domesticity is also something that feminist scholars have emphasized with regards to the process of homemaking. Dayaratne and Kellett argue that homemaking is a process that "continues and consolidates itself with each event of significance that adds to the sense of home by overcoming the obstacles which might diminish it" $(2008,66)$. This includes, as I have already suggested, both traumatic as well as felicitous events, because, "home is a place of comings and goings, of living and dying, of moving in and moving out, of material decay and repair" (Baxter and Brickel, 20I4, I40).

\section{Routine care and securing the future through the present}

If Navaro-Yashin sees the un-homely as a force to be contained, Das's assessment is less optimistic. For the women Das worked with in India and the United States respectively, erasing the historical traumas of partition, or the deep uncertainty inflicted by extreme poverty was never truly an option. Das talks about an ethic of 'endurance' and 'acceptance' where women learn to live with these disruptive and un-homely affects (2008; 2013). For Das, domestic care is less about containment, and more about the will to carry on despite hardships, and to make caring decisions wherever possible, knowing that often one cannot act fully in line with one's intentions and ethics, and that daily life requires a myriad of forms of 'making do'. Similarly, Han (20I2) talks about an ethics of 'waiting' amongst the urban poor, where, when faced with an unpredictable world, simply holding on and maintaining relationships despite uncertainty becomes a caring act. Waiting may not quash uncertainty, but it may allow for new possibilities to emerge. 
the un-homely is

not something

that is simply

abided, but some-

thing which itself

becomes repro-

duced as a part

of routines of

care
Both of these arguments are important correctives to the notion that the 'un-homely' can simply be contained and forgotten. Inscribed in wounded landscapes, and in the uncertainty that pervades everyday livelihoods, management is clearly not always an option. In this final section, however, I want to extend the work of Das and Han to argue that the un-homely is not something that is simply abided, but something which itself becomes reproduced as a part of routines of care. This reproduction becomes a way of taming, though never eliminating or containing the un-homely, and making it something that is more one's own, and easier to live with.

It was a typically sunny Sunday in April when I was on my way to pick up Amina from her house for a stroll downtown. When I arrived, however, I found Amina in the midst of her weekly cleaning. As she was quick to tell anyone who asked her about how she spent her Sundays, Amina would always say: "Kif dima. Hammamit, jeffeft, ghesselt, wa teferejt telfaza." (As usual. I went to the hammam, scrubbed the floors, did laundry, and watched TV). While the scholarly literature has tended to see routines as the emblem of an alienating modernity, or in Ben Highmore's formulation "a straightjacket of dull repetition" $(2004,307)$, drawing on ethnographic material gleaned with Amina's help, I argue that routines can also be instrumental in contributing a sense of stability and control to lives otherwise marked by chronic insecurity (cf. Dejarlais I997). As such, the routines that Amina claimed defined her monotonous life also provided her with a sense of structure and stability, in a context in which contingency was abundant (cf. de Certeau 1984; Lefebvre I991; de Certeau and Giard 1998; Highmore 2004). I argue that the repetitious nature of what have otherwise been considered chores reveals meaningful reinterpretations of lived experience. Paradoxically, however, in taking control over reproducing her everyday world, Amina also, in subtle ways, became involved in reproducing the sense of un-homeliness that pervaded it.

\section{Hammam}

W

hereas during the week the body performed the routines that ensured the running of everyday life, once a week it worked on itself in a ritualized form of routine that allowed for its renewal (cf. Turner ${ }_{1967}$ ). This was most powerfully exemplified by the weekly trips to the local hammam. A Moroccan version of the Turkish public bath, the hammam continues to occupy a central space in the lives of ordinary Moroccans, particularly for those like Amina, who did not have a bathroom at home. ${ }^{\text {I }}$ Early on in my fieldwork Amina invited me to join her for her weekly hammam visits, an invitation I took up several times, during that year. On these occasions we would wake up at half past six in the morning and assemble the various things that make up the arsenal needed at the hammam. Amina would get her sister dressed and prepare their respective duffle bags containing a change of clothes, 
bathrobes and towels, slippers and toiletries. Holding three large pink plastic pails, two little plastic stools and a soft, rolled up bathroom mat we would head out into the deserted alleyway as the dawn was slowly coloring the sky a bright hue. "If we are there by 7 we can avoid the crowds. It's better when it's empty," is what Amina said to me on our first visit in order to justify our early rise.

In her writing on beauty rites and rituals in Casablanca, Susan Ossman claims that people go to the hammam as a form of leisure, "in the same way that the middle and upper classes frequent sports clubs to relax" $(2002,182)$. Although the analogy contained in this statement seems to imply that going to the hammam is an activity that only certain social categories engage in, she does explain that there are various types of hammams, from the most basic to the more luxurious and spa type. I would add that the experiences one can have in these spaces differ accordingly, and I would further argue that in the case of the hammam sha'abi (the working-class hammam), such as the one Amina and I frequented, leisure was but one component of a complex form of routinized ritualized work performed with and on the body.

Once inside the hammam, Amina would choose a spot next to the tiled wall and lay out her stool and bathmat, after which she would help her sister sit down. From that point onward we had to engage in a particular sequence of acts and gestures so as to achieve a 'proper' hammam experience. If I ever skipped a step or tried to perform them in a different order Amina would be sure to gently chide me. From a small faucet in the wall Amina would fill the buckets with a mix of scalding hot and cold water. Pushing the buckets along the floor she would then use a small plastic cup to scoop up water from the bucket and douse it on herself. The next step entailed applying the savon beldi (traditional black soap made from olives) all over the body and allowing it 'to work' on the skin, which aided in the following step: exfoliating of skin over the entire body with the help of a rough black glove. This step was the most laborintensive part of the process, and I was encouraged to scrub myself vigorously from head to toe in order to remove all my dead skin cells. Women usually help each other for exfoliating their backs, and in some hammams it was possible to ask one of the female attendants to help with this exercise in exchange for a small fee. However, in hammams like the one in Amina's quarter, most women worked on themselves, diligently and with intention, using gestures and movements that echoed those they employed in scrubbing their houses.

Shrouded in steam, some women exchanged words with their friends or neighbors, but mostly the atmosphere was not the boisterous, socially effervescent one that Ossman hints at in her narrative, and which risks falling in the trap of many Orientalist depictions of the hammam as sensuous sociality $(2002,183)$. There were few points in the cleaning ritual at which the body was not performing some form of work, either on itself or on another. Specifically, Amina did not only have to perform her own cleaning ritual but that of her sister as well. After the exfoliation, she would use the water in the pails to rinse herself off and proceed with 
washing her own and her sister's hair, shaving, lathering themselves with shower cream, and repeating the rinsing several times. In between moments of handling her own body or that of her sister, she would rinse away the dirty water towards the drain in the middle of the room, detangle hairs from her comb or replace scrubbing gloves, soaps and other such things in the area around us. In this way, each woman created a bubble of watery activity around herself in the hammam, while constantly managing the boundaries of this space so that one did not splash water on one's neighbor, or allow tufts of hair to flow onto someone else's bathmat. Squatting on the tiny plastic stools fit for a toddler, or sitting on a bathmat, body posture in the hammam also had to be managed to ensure modesty, which meant that comfort was not always a priority.

After the final rinse, we would move into the first room of the hammam, put on our bathrobes or towels and exit into the much cooler air of the changing room. As we got dressed and pulled a woolly djellaba over our clothes, Amina would always remark on the smoothness of our "new" skin. As soon as we returned to her house she would bring out the blankets, and at io a.m. on a Sunday we would be ready to take a long nap as a reward for the thorough cleaning performed on our bodies.

Work performed so laboriously on the body that one requires rest afterwards can be seen as a form of what Mary Douglas has identified as the prophylactic practices necessary for "ordering" the world through the separation of matters deemed polluting, as a way of "articulating the body" and re-affirming its being (2002, I 59). Female bodies in particular have been traditionally associated with polluting substances and the fluid and "slimy" aspects of corporeal excreta, and thus requiring specialized forms of cleansing rituals (Dürr and Jaffe 2010). The cleansing ritual was also seen as a way of maintaining one's health, and the common greeting for those who had just exited the hammam was a hearty "Bi sahatek!" (To your health). This greeting was also meant to ward off the evil eye, something one was supposedly more vulnerable to when freshly cleansed.

It should be noted, that neither Amina, nor any of my other close female informants whom I accompanied on visits to the hammam attached solely hygienic or solely symbolic/religious significance to their cleansing rituals. As the considerable literature on bodily ritual and pollution has described for other locales (see Das i992; Burke i996; Nguyen and Peschard 2003), such cleaning routines and their skillful execution produced an entirely different performance register, an 'ordinary' ritual that contained and blended ideas about hygienic concerns with symbolic meanings. In fact, when prompted by my questions, Amina also emphasized the pragmatic aspects of the hammam visit, such as the cosmetic benefits of exfoliating once a week or the need to give her sister a thorough bath, given the lack of proper facilities in their own home.

For Amina, the hammam was a ritual of renewal. But taking ownership of self-renewal also meant taking ownership of the precarity that pervaded her life. The use of the hammam made the small and nonfunctioning shower something manageable, but it also consolidated it as a symbol of insecurity and poverty. A routine focused on care through 
cleansing over luxury, and Amina's insistence on a practical attitude as a source of comfort, again asserted control, but also reproduced a sense that this was where her place in the world was. These, I want to argue, were not unconscious acts of 'social reproduction' but, in part, deliberate acts of ownership, which involved appropriating elements of one's precarious position into routines and rituals focused around the body and around skill, designed to be empowering and embodying. By laboriously performing these acts of care giving, Amina was able to make her life with her sister something of her making - rather than something solely determined by outside forces.

\section{Conclusion}

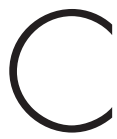

aring and being taken care of are some of the ways in which a sense of well-being comes into the world. In Hay Mohammadi, both people and places have been maligned for decades by elites and political actors who at times withdrew their care from the inhabitants while at others outright punished them only to release them into the arms of the destabilizing effects of economic liberalization and precarious living conditions. In this context well-being becomes a delicate balancing act between pragmatic needs and "silent acts of kindness". As a consequence, I have tried to show how feeling at home on the margins of Casablanca is oftentimes achieved through ambivalent caregiving and caretaking practices. In a context in which the neighborhood has become synonymous with state-inflicted trauma, and current degradation and poverty are seen as its side effects, learning how to inhabit one's home in the face of constant contingency becomes a cherished skill. And this skill often involves not only containing, but also often re-producing and caring for the elements of un-homeliness in one's life. These elements can include personal grief alongside historical trauma and the unending burden of securing livelihoods through skillful routines. I suggest that some of these elements of care, such as the cleaning of home and body, work to keep in check the ever-present un-homeliness, while others, such as caring for a disabled family member inside the decaying architecture of the neighborhood, seek to incorporate and normalize it. Deployed on the level of everyday life, the skillful managing of caregiving and homemaking manifested by Amina, invested otherwise mundane routines with the power to stabilize a chaotic present, and allowed her to envision a better future emerging from it.

Amina's example speaks to the challenges faced by marginalized urban dwellers in Morocco and elsewhere who must co-habit with the darker and more desolate parts of their lives and their homes. The ethnographic story I provide here reveals some of the ways in which those who inhabit the urban margins are forced to re-cast their living conditions and cope with constraints through the subtle reworking of existing forms of gendered skill and care. This exploration of care on the margins of the city forces us to re-think concepts such as home, well-being and morality.
Learning how to inhabit one's home in the face of constant contingency becomes a cherished skill 
As Clara Han has so poignantly demonstrated in her work, care itself is not a stable concept, but something that is woven and constantly reworked through the circumstantial nature of social and physical spaces and the relationships that develop on the urban margins (2012).

\section{NOTES}

Acknowledgements. I would like to thank Farhan Samanani and Johannes Lenhard for putting together this special issue and for their incredibly helpful and supportive feedback along the way. The research that this article is based on was funded by a Wenner-Gren Dissertation Fieldwork grant, a UK ESRC grant, and a FURS Writing up grant. Significant parts of this article were written as a fellow of the Max Planck Research Group 'Objects in the contact zone - the cross-cultural lives of things' at the Max Planck Institute in Florence, Italy.

IThis article is based on my $\mathrm{PhD}$ research, which studied the interplay between state planning policies, social development programs and the everyday practices of inhabitants in Hay Mohammadi in an attempt to show how the production of space and class are intricately linked in the urban margins of Morocco.

${ }^{2}$ I use a pseudonym in order to protect my interlocutor's privacy.

${ }^{3}$ The term Karyane Centra was the preferred terminology employed by my interlocutors in Hay Mohammadi. I also use the term bidonville as opposed to its English equivalent (slum) because I believe it captures the local specificity of this worldwide phenomenon.

${ }^{4}$ For a history of Morocco and its place in the wider North African context see Laroui (1982) and Miller (2013).

${ }^{5}$ Originally the bidonvilles were not a synonym for poverty, but more akin with early frontier settlements., Écochard was aware of this, cautioning against their further degradation $(1950,5)$.

${ }^{6}$ For an exception see the Lafarge company worker housing built before 1939 by Edmond Brion (Cohen and Eleb 2002).

${ }^{7}$ This led to the creation of individual housing plots with rooms arranged around an open patio. Écochard's grid was celebrated by the architecture world and spread to other areas of Morocco. See Chaouni (2OII).

${ }^{8}$ Triggered by a controversial educational regulation, the I965 riots became the shorthand for the three days of student protests, which also led to the creation of the Marxist student movement on March 23. See Miller (2013).

${ }^{9}$ The early i980s saw a series of 'bread riots' erupt across the Arab world in response to IMF supported lifting of state food subsidies. See Lockman (i 994).

${ }^{10}$ See http://www.moroccoboard.com/viewpoint-5/36r-nora-fitzgerald/5663-morocco-women-going-extra-mile-in-ramadan

${ }^{\text {I } M a n y ~ l o w e r-c l a s s ~ i n h a b i t a n t s, ~ e v e n ~ t h o s e ~ w h o ~ o w n e d ~ a ~ s h o w e r, ~}$ continued to go to the hammam because it was thought to allow for a proper, more thorough body cleaning. 


\section{References}

Ait Mouss, Fadma. 20I I. "Portrait d'une ménagère casablancaise." In Casablanca: Figures et scènes métropolitaines, edited by Peraldi, Michel and Tozy, Mohamed. Paris: Karthala.

Avermaete, Tom. 2005. Another Modern: The Post-war Architecture and Urbanism of Candilis-Josic-Woods. Rotterdam: NAi.

Bachelard, Gaston. 1994. The Poetics of Space. Boston: Beacon Press.

Baxter, Richard and Brickel, Katherine. 20I4. "For Home UnMaking." Home Cultures I I (2): I $33-43$.

Bhabha, Homi K. 1994. The Location of Culture. London: Routledge.

Biehl, João. 2013. Vita: Life in a zone of social abandonment. Berkeley: University of California Press.

Blunt, Alison and Dowling, Robyn. 2006. Home (Key Ideas in Geography). New York: Routledge.

Burke, Timothy. I996. Lifebuoy Men, Lux Women: Commodification, Consumption, and Cleanliness in Modern Zimbabwe. London: Leicester University Press.

de Certeau, Michel and Giard, Luce. I998. The Practice of Everyday Life. Volume 2: Living and Cooking. Minneapolis: University of Minnesota Press.

Chaouni, Aziza. 20 г r. "Depoliticizing group GAMMA." In Third World Modernism: Architecture, Development and Identity, edited by Lu, Dunafang. New York: Routledge.

Cohen, Jean-Louis and Eleb, Monique. 2002. Casablanca. Colonial Myths and Architectural Ventures. New York: The Monacelli Press.

Crapanzano, Vincent. I980. Tuhami: Portrait of a Moroccan. Chicago: University of Chicago Press.

Das, Veena. I992 [1977]. Structure and Cognition: Aspects of Hindu Caste and Ritual. Delhi: Oxford University Press.

-. 2007. Life and Words: Violence and the Descent into the Ordinary. Berkeley: University of California Press.

-. 2008. "On Modalities of the Domestic." Home Cultures 5(3):349-72.

-. 2013. "Neighbours and acts of silent kindness." HAU Journal of Ethnographic Theory $3(\mathrm{I}): 2 \mathrm{I} 7-20$.

Dayaratne, Ranjith and Kellett, Peter. 2008. "Housing and home-making in lowincome urban settlements: Sri Lanka and Colombia." Journal of Housing and the Built Environment 23(I):53-70.

De Certeau, Michel. 1984. The Practice of Everyday Life, translated by Steven Rendell. Berkeley: University of California Press.

Dejarlais, Robert. 1997. Shelter Blues: Sanity and Selfhood Among the Homeless. Philadelphia: University of Pennsylvania Press.

Douglas, Mary. 2002 [1966]. Purity and Danger: An Analysis of Concepts of Pollution and Taboo. London: Routledge.

Dürr, Eveline and Jaffe, Rivke (eds.). 2oro. Urban Pollution: Cultural Meanings, Social Practices. New York: Berghan Books.

Écochard, Michel. I950. "Urbanisme et construction pour le plus grand nombre." Conférence donnée le io février i950 à la Chambre de Commerce et de l'Industrie de Casablanca à l'occasion de l'inauguration de l'Institut Technique Français du Bâtiment et des Travaux Publics du Maroc, Annales de l'Institut Technique du Bâtiment et des Travaux Publics, $\mathrm{n}^{\circ}$ I 48, Paris.

—. I955. "Habitat Musulman au Maroc." L'Architecture d'Aujourd'hui 6o(June):3640.

-. I955a. Casablanca: Le Roman d'une Ville.

El Bouih, Fatna. 2008. Talk of Darkness. Austin: University of Texas Press. 
Freud, Sigmund. I9I9. "The 'Uncanny'." In The Standard Edition of the Complete Psychological Works of Sigmund Freud, Volume XVII (I9I 7-1919): An Infantile Neurosis and Other Works, 2 I 7-56. London: The Hogarth Press.

Gilson Miller, Susan. 2013. A History of Modern Morocco. Cambridge: Cambridge University Press.

Han, Clara. 201 2. Life in Debt: Times of Are and Violence in Neoliberal Chile. Berkeley: University of California Press.

Highmore, Ben. 2004. "Homework: Routine, Social Aesthetics and the Ambiguity of Everyday life." Cultural Studies I 8(2-3):306-27.

Hollows, Joanne. 2008. Domestic Cultures. Maidenhead: Open University Press.

hooks, bell. r 99. Yearning: Race, Gender and Cultural Politics. Boston: Turnaround.

Jentsch, Ernst. 1906. "On the Psychology of the Uncanny." ("Zur Psychologie des Unheimlichen"). In Psychiatrisch-Neurologische Wochenschrift 8.22 (25 Aug. I 906): 195-I 98 and 8.23 (I Sept. I906): 203-205.

Kleinman, Arthur. 2007. "The Experiential Basis of Subjectivity: How Individuals Change in the Context of Societal Transformation." In Subjectivity: ethnographic investigations, edited by Biehl, J. G., Good, B., \& Kleinman, Arthur. Berkeley: University of California Press.

Laroui, Abdallah. 1982. Histoire du Maghreb. Paris: Maspero.

Lefebvre, Henri. I99. The Production of Space. New York: Wiley.

Lockman, Zachary (ed.). I994. Workers and Working Classes in the Middle East: Struggles, Histories, Historiographies. Albany, NY: State University of New York Press.

Martens, Lydia. and Scott, Sue. 2005. "The Unbearable Lightness of Cleaning': Representations of Domestic Practices and Products in Good Housekeeping Magazine (UK): I95 I-200I". Consumption, Markets and Culture 8(3):37I-409.

Massey, Doreen. I994. Space, Place, and Gender. Minneapolis: University of Minnesota Press.

Mitchel, Timothy. 2002. Rule of Experts: Egypt, Techno-politics, and Modernity. Berkeley: University of California Press.

Nguyen, Vinh-Kim and Peschard. Karine. 2003. "Anthropology, Inequality, and Disease: A Review", Annual Review of Anthropology 32:447-74.

Navaro-Yashin, Yael. 20I 2. The Make-Believe Space: Affective Geography in a Postwar Polity. Durham: Duke University Press.

Nora, Piere. 1989. "Between Memory and History: Les lieux de memoire." In Representations, No. 26, Special Issue: Memory and Counter-Memory, 7-24.

Ossman, Susan. 1994. Picturing Casablanca: Portraits of Power in a Modern City. Berkeley: University of California Press.

-. 2002. Three Faces of Beauty: Casablanca, Paris, Cairo. Berkeley: University of California Press.

Rabinow, Paul. 1989. French Modern: Norms and Forms of the Social Environment. Chicago: University of Chicago Press.

Rachik, Abderrahmane. 2002 Casablanca: l'urbanisme de l'urgence.

Slyomovics, Susan. 2012. "Fatna El Bouih and the Work of Memory, Gender, and Reparation in Morocco." Journal of Middle East Women's Studies 8/ז:37-62.

Taki, Najib. 2015. Memoires Carriere Centrale. Casablanca: Editions La Croisée des Chemins.

Turner, Victor. 1967. "Betwixt and Between: The Liminal Period in Rites de Passage." In The Forest of Symbols. New York: Cornell University Press.

Vidler, Anthony. I 992. The Architectural Uncanny: Essays in the Modern Un-homely. Cambridge: MIT Press.

Williams, Joan. 2000. Unbending Gender: Why Family and Work Conflict and What to do about it. New York: Oxford University Press. 